\begin{tabular}{|lcccccc|}
\hline $\begin{array}{l}\text { Social Work/Maatskaplike } \\
\text { http://socialwork.journals.ac.za/pub }\end{array}$ & Werk & $\begin{array}{c}\text { Vol 51 No 3; Issue } \\
\text { doi:http://dx.doi.org/51-3-454 }\end{array}$ & 4 \\
\hline
\end{tabular}

VIEWS OF SERVICE PROVIDERS ON SERVICES RENDERED TO PEOPLE WITH DISABILITIES AND ON THE NEED FOR FAMILY PRESERVATION SERVICES

Marianne Strydom

The article reflects the research findings of a study that was initiated because a welfare organisation delivering social work services to people with disabilities was investigating the possibility of developing a family preservation programme. The aim of the investigation was to explore the views of service providers on services delivered to persons with disabilities to determine the need for family preservation services. It was found that limited people power and funds placed serious constraints upon services. However, a clear link between the aims of family preservation and the needs of families caring for a relative with a disability has been established. 


\section{VIEWS OF SERVICE PROVIDERS ON SERVICES RENDERED TO PEOPLE WITH DISABILITIES AND ON THE NEED FOR FAMILY PRESERVATION SERVICES}

\section{Marianne Strydom}

\section{INTRODUCTION}

The World Health Organisation reported that about $40 \%$ of Africa's population consists of people with disabilities, $10-15 \%$ of them being children of school-going age (Chitereka, 2014). The 2011 Census (Statistics South Africa, 2014) indicated a national disability prevalence rate of $7.5 \%$, with a $5 \%$ prevalence rate in the Western Cape province. It is estimated that between $1 \%$ and $1.8 \%$ of employed people in South Africa have a disability (CASE, 1999; Maja, Mann, Sing, Steyn \& Naidoo, 2011; Republic of South Africa, 1997). This means that the majority of people with disabilities depend on a social disability grant for survival. Graham, Selipsky, Moodley, Maina and Rowland (2010) rightly state that people who contend with disabilities in South Africa face a range of challenges, mainly because they are often living in poverty.

Various organisations and professions in South Africa render services to persons with disabilities. NGOs delivering social work services form part of these organisations. Research in SA found that $31 \%$ of respondents with a disability indicated that a social worker was the predominant form of social support available to them (Graham et al., 2010), while young people with disabilities seem to be more aware of social workers than of home-based carers, community rehabilitation workers and rehabilitation therapists (Lorenzo \& Cramm, 2012). Social workers are thus important role players in rendering services to people with disabilities.

The study was initiated because a welfare organisation delivering social work services to people with disabilities was investigating the possibility of developing family preservation services for these people. It was regarded as important to explore the views of service providers about the types of services delivered to persons with disabilities, as well as the obstacles that are experienced in service delivery, before the need for family preservation services could be determined. Within this context the focus of this paper is to present the views of service providers on services rendered to persons with disabilities, as well as the obstacles experienced in service delivery. The possible link and the aspects that should be focused on in the delivery of family preservation services were identified.

\section{BACKGROUND INFORMATION}

Family preservation is the primary model utilised by social workers when rendering child and family social work services where children are abused and neglected. The aim of family preservation is to prevent the statutory removal of children by increasing the coping skills of families through strengthening family bonds and facilitating the family's utilisation of formal and informal resources, thereby improving the functioning of the 
family (Al, Stams, Bek, Damen, Asscher \& Van der Laan, 2012; Ryan \& Shuerman, 2004:347; Tracy, 1995:980).

Family preservation services consist of different types of services such as family support services and family-centred services (Pecora, Fraser, Nelson, McCroskey \& Meezan, 1995; Tracy, 1995). Family support services refer to the resources as well as supportive and educational services that should be available to parents in communities. The focus of these services is on giving families access to services or networks in communities to enable and support them to care for their children (Chaffin, Bonner \& Hill, 2001; Pithouse \& Tasiran, 2000; Warren-Adamson, 2006). Parent education programmes, feeding schemes, play groups, and school- or community-based resource centres are examples of such services (Armstrong \& Hill, 2001; Pierson, 2002; Tracy, 1995).

Family support services as an integral component of family preservation services are important for people with disabilities as the literature and policy documents indicate that they need a variety of services from community agencies. The role and task of social workers are to link these persons with these community resources, as well as raising awareness in communities on issues of disability (Chitereka, 2014; Republic of South Africa, 1997). With regards to children with disabilities, community-based support should be available to parents, care-givers and community members (Department of Social Development, Department of Women, Children and People with Disabilities \& UNICEF, 2012; Philpott \& McLaren, 2011). These types of services are very important in the South African context as policy documents indicate that factors such as insufficient financial resources and the lack of community-based resources such as home-based care often negatively affect the abilities of families of people with disabilities to support them, and that they should have access to these services (Republic of South Africa, 1997; Republic of South Africa, Western Cape Department of Social Development, n.d.). Families living with a family member needing care should thus have access to community-based support programmes such as home-based care and support groups. However, Graham et al. (2010) state that despite policies in South Africa that intend to support people with disabilities, there is still a gap between policy and the experience of services.

Another type of family preservation service is family-centred services. Through these services social workers attempt to prevent the family's problems and needs from reaching crisis proportions. The intervention consists of therapeutic services such as counselling, and educational services such as the development of skills in family members (Cash \& Berry, 2003; Juby \& Rycraft, 2004; Martens, 2009; Mullins, Chueng \& Lietz, 2011). Concrete services such as assisting and enabling families to obtain housing, providing food and clothing, and engaging family members in life skills programmes or empowering them to utilise community resources are included in familycentred services (Maluccio, Pine \& Tracy, 2002; Mullins et al., 2011; Tracy, 1995).

When rendering social work services to people with disabilities, social workers provide counselling to enable adjustment to the disability, inter alia by focusing on various problems of a personal and interpersonal nature. Social workers will include the family 
in counselling where necessary to facilitate understanding of the nature of the disability, to support the person with a disability, as well as to improve the capacity of care-givers (Chitereka, 2014).

It is clear that family preservation services when applied to people with disabilities would focus on enabling the family to care effectively for such a relative and on fully utilising community resources. Services should focus on proper care of the person within the family unit or, with no other option, to have the person admitted to a residential facility.

\section{RESEARCH METHODOLOGY}

An empirical investigation was undertaken in the Western Cape metropolitan and surrounding areas. A combination of quantitative and qualitative approaches was used (Fouché \& De Vos, 2005). An exploratory and descriptive research design was used (De Vos, Strydom, Fouché \& Delport, 2011), as these designs are suitable for qualitative as well as quantitative methods of research (Fouché \& De Vos, 2005).

The population (De Vos et al., 2011) consisted of organisations rendering services to persons with disabilities in the geographical areas where the investigating organisation delivered services. Only service providers who had been delivering services to persons with disabilities for at least a year were included in the study; thus purposive selection according to the non-probability selection classification (De Vos et al., 2011; Strydom, 2005) was used for sampling. Service providers in this study refers to organisations such as NGOs, which render services to persons with disabilities, both in terms of broader social work services and services specifically geared towards persons with disabilities. Service providers at senior citizen homes, residential facilities and schools for persons with disabilities, all within the service area of the organisation conducting the investigation, were also included. This ensured that the views of different service providers were taken into account.

A self-administered semi-structured questionnaire (De Vos et al., 2011) was developed to gather quantitative and qualitative data. Open and closed-ended questions were included in the questionnaire, with the main focus being on the views of service providers on the services rendered to persons with disabilities. Social workers at the investigating organisation were informed about the aim of the study, and uncertainties about the investigation were clarified before data collection. The self-administered questionnaires were distributed to the service providers through the social workers at the organisation conducting the investigation.

Respondents were informed of the nature of the study and were free to decide whether or not to complete the self-administered questionnaire. Participation in the study was therefore voluntary and no organisation was under any obligation to participate in the study. The respondents were involved in services rendered to persons with disabilities and no direct contact was made. The respondents remained anonymous and no participants were identified. Fifty-four $(\mathrm{N}=54)$ self-administered questionnaires were returned. Collected data were kept in a secure cabinet and safeguarded against improper 
access. All information was treated as confidential, in accordance with the ethical code of the social work profession.

The data obtained from the questionnaire were typed and grouped according to the different questions in the questionnaire. The quantitative data were presented in tables and figures. The emerging themes, sub-themes and categories were identified through colour coding and responses that supported the subthemes and categories were grouped together. The frequency of responses was calculated by counting the number of similar responses and converting them into percentages to determine the dominant trends within a specific theme. These themes, sub-themes, categories and narratives were presented in tabular format.

\section{Aim and objectives of the study}

The aim of the investigation was to determine the views of service providers on the services delivered to persons with disabilities.

The objectives of the research were to:

- describe the profile of service providers;

- explain the views of service providers with reference to any obstacles experienced in service delivery to persons with disabilities;

- determine the views of service providers on the possible focus of family preservation services for persons with disabilities.

\section{RESULTS OF THE RESEARCH}

The results of the research study will be discussed below.

\section{PROFILE OF SERVICE PROVIDERS AND SERVICE USERS}

The majority $(26=48.1 \%)$ of the respondents identified their organisation as an NGO service provider rendering social work services only to disabled persons $(18=33.3 \%)$ or rendering broader social work services $(8=14.8 \%)$ also to persons with disabilities. The rest of the respondents $(28=51.8 \%)$ hailed from service providers such as schools for children with physical disabilities, clinics and residential care facilities.

The predominant profession of the respondents was that of social work $(19=35.2 \%)$ followed by respondents in management positions $(9=16.6 \%)$ The rest of the respondents classified their profession or line of work in the organisation as social auxiliary workers, nurses, physiotherapists, teachers, occupational therapist, and psychologist. The various professionals and non-professionals included in the study corresponded with the range of services rendered to people with disabilities. As to the position of the respondents in their respective organisations, more than a third $(19=35.2 \%)$ were managers or chief executive officers.

Service providers render services to people presenting with all forms of disabilities. The age group which seems to need most service rendering is the 30 to 59 years category $(36=66.6 \%)$. However, service providers participating in this study deliver services to all ages ranging from birth to above 60 years of age. 
The services rendered by most of the service providers pertains to social work, including residential and rehabilitation services. The majority $(11=20.4 \%)$ of the programmes offered by the service providers are protected workshops and skills development programmes. Other programmes include daily programmes for children $(7=12.8 \%)$, life skills programmes $(6=11.1 \%)$, and arts and crafts programmes $(4=7 \%)$. Only $9(16.6 \%)$ of the programmes are aimed at supporting the family $(6=11.1 \%)$ and at raising awareness in the community $(3=5.5 \%)$. Programmes aimed at the support of the family as well as the broader community are thus not regularly available.

\section{VIEWS OF SERVICE PROVIDERS ON SERVICES RENDERED TO PERSONS WITH DISABILITIES}

The views of the participants on the services rendered to persons with disabilities were determined. The data gathered are discussed in the following sections.

\section{Greatest obstacles experienced by organisations when rendering services to persons with disabilities}

The participants were asked to identify the three greatest obstacles encountered by their organisations in their service delivery to persons with disabilities. The sub-themes and categories that emerged, as well as the narratives from the participants, are presented in Table 1.

\begin{tabular}{|c|c|c|}
\hline \multicolumn{3}{|c|}{$\begin{array}{c}\text { TABLE } 1 \\
\text { THEME: OBSTACLES EXPERIENCED BY ORGANISATIONS WITH } \\
\text { REGARDS TO SERVICE DELIVERY TO PERSONS WITH DISABILITIES }\end{array}$} \\
\hline SUB-THEME & CATEGORY & NARRATIVES \\
\hline \multirow[t]{3}{*}{$\begin{array}{l}\text { Insufficient } \\
\text { funds in } \\
\text { organisations }\end{array}$} & $\begin{array}{l}\text { 1. Ineffective service } \\
\text { delivery }(22=40.7 \%)\end{array}$ & $\begin{array}{l}\text { "Scarcity of funds to render services effectively." } \\
\text { "As a result of financial problems ... no } \\
\text { programmes." } \\
\text { "Finances: Insufficient state subsidies. Large area } \\
\text { - cannot render effective services everywhere." } \\
\text { "Too little transport to do regular home visits." }\end{array}$ \\
\hline & $\begin{array}{l}\text { 2. Shortage of } \\
\text { professional human } \\
\text { resources } \\
(12=22.2 \%)\end{array}$ & $\begin{array}{l}\text { "Human resources - too few social workers for the } \\
\text { service area." } \\
\text { "Lack of professional human resources." } \\
\text { "Scarcity of social services, physiotherapists and } \\
\text { OTs (Occupational therapists)..." }\end{array}$ \\
\hline & $\begin{array}{l}\text { 3. Shortage of } \\
\text { trained non- } \\
\text { professional staff } \\
(3=5.6 \%)\end{array}$ & $\begin{array}{l}\text { "Not enough trained home care-givers." } \\
\text { "Lack of home visiting services like help with } \\
\text { cleaning of houses and the preparation of meals." } \\
\text { "Uninformed/untrained staff." }\end{array}$ \\
\hline \multirow[t]{2}{*}{$\begin{array}{l}\text { Insufficient } \\
\text { resources in } \\
\text { communities }\end{array}$} & $\begin{array}{l}\text { 1. Lack of public } \\
\text { transport } \\
(14=25.9 \%)\end{array}$ & $\begin{array}{l}\text { "Lack of public transport for disabled persons. } \\
\text { They cannot reach the organisations." } \\
\text { "Poor transport system." }\end{array}$ \\
\hline & $\begin{array}{l}\text { 2. Lack of } \\
\text { community } \\
\text { resources }(4=7.4 \%)\end{array}$ & $\begin{array}{l}\text { "Community resources lacking." } \\
\text { "Resources not always available." }\end{array}$ \\
\hline
\end{tabular}


The main sub-themes (Table 1) that emerged as obstacles to service delivery are insufficient funds in the organisation and lack of resources in communities. These subthemes are discussed below.

\section{(a) Insufficient funds in organisations}

The first sub-theme to emerge is that organisations have insufficient funds, highlighted by more than half $(35=64.8 \%)$ of the responses. Three categories indicate the areas where insufficient funds play a role. One of these relates to ineffective service delivery $(22=40.7 \%)$, where programmes cannot be implemented and where lack of transport hampers home visits.

The other two categories point to a shortage of professional people $(12=22.2 \%)$ such as social workers, as well as other professionals people, in service delivery. There also seems to be a shortage of trained non-professional people $(3=5.5 \%)$ such as care-givers and home visitors to deliver home visiting services. These findings - that insufficient funds in the organisation hamper programmes initiation, and that the lack of people power adversely affects service delivery - confirm the findings of other studies (Brown \& Neku, 2005; Streak \& Poggenpoel, 2005; Strydom, 2010; Weyers \& Van den Berg, 2006) regarding the obstacles experienced by NGOs rendering social work services in South Africa.

\section{(b) Insufficient resources in communities}

Insufficient resources in communities were identified as another sub-theme by the participants. The lack of suitable public transport for persons with disabilities $(14=25.8 \%)$ was identified as the first category that adversely affects service delivery, as the person with a disability finds it difficult to attend programmes offered by service providers. As already indicated in this study, insufficient funding prevents regular home visits and affects service delivery. Public transport remains a challenge in SA, as other studies noted that public transport should be more disability friendly (Graham et al., 2010). The attitudes of taxi drivers and their passengers were also found to be not very accommodating towards young people with disabilities (Lorenzo \& Cramm, 2012).

The second category emphasised the lack of resources in the community $(4=7.4 \%)$. The lack of services and programmes for persons with disabilities was in fact identified as a challenge by the South African Human Rights Commission (2006). This lack in communities was also identified by social workers in the field of child and family welfare (Strydom, 2008). Social workers indicated that community resources were limited and/or over-utilised, that families often did not have the finances available to utilise the resource, and that organisations did not have the resources to support the families financially.

\section{The experiences of service providers with regards to the involvement of} family members with a person with a disability in the household

Family preservation is focused on the effective care of children within the family. Intervention therefore includes the strengthening of family bonds. In South Africa people with disabilities are mostly cared for in the family home. Participants were asked to describe their experiences as service providers regarding the involvement of family 
members with a family member needing care. The sub-themes, categories and narratives are displayed in Table 2.

\section{TABLE 2}

THEME: EXPERIENCES OF SERVICE PROVIDERS REGARDING THE INVOLVEMENT OF FAMILY MEMBERS WITH PERSONS WITH DISABILITIES

\begin{tabular}{|c|c|}
\hline $\begin{array}{l}\text { SUB-THEME AND } \\
\text { CATEGORY }\end{array}$ & NARRATIVES \\
\hline $\begin{array}{l}\text { Sub-theme: } \\
\text { Varying involvement of family } \\
\text { members } \\
\text { Category: } \\
\text { 1. Limited involvement of family } \\
\text { members } \\
(27=50.0 \%)\end{array}$ & $\begin{array}{l}\text { "In most cases severely limited or no contact at } \\
\text { all." } \\
\text { "Family is only slightly involved; they consider } \\
\text { the disabled person a disgrace." } \\
\text { "Some of the families do not care for them and } \\
\text { misuse them." }\end{array}$ \\
\hline $\begin{array}{l}\text { Sub-theme: } \\
\text { Varying involvement of family } \\
\text { members } \\
\text { Category: } \\
\text { 2. Sufficient involvement of family } \\
\text { members }(18=33.3 \%)\end{array}$ & $\begin{array}{l}\text { "They are involved in their families. They are } \\
\text { well treated." } \\
\text { "Usually the families are involved." } \\
\text { "In general the families are supportive of } \\
\text { persons with disabilities." }\end{array}$ \\
\hline $\begin{array}{l}\text { Sub-theme: } \\
\text { Family members are ignorant about } \\
\text { disability } \\
\text { Category: } \\
\text { 1. Lack of information about the } \\
\text { type of disability and the necessary } \\
\text { care }(5=9.3 \%)\end{array}$ & $\begin{array}{l}\text { "Family members are ignorant about the type of } \\
\text { disability and how to care for the person } \\
\text { sufficiently." } \\
\text { "...they have little correct } \\
\text { information/knowledge about the disability". } \\
\text { "... but ignorance, poor socio-economic } \\
\text { circumstances and illiteracy play a role, and then } \\
\text { we have a problem with substance abuse". }\end{array}$ \\
\hline $\begin{array}{l}\text { Sub-theme: } \\
\text { The family has insufficient funds to } \\
\text { support the person with a disability. } \\
\text { Category: } \\
\text { 1. Financial, emotional and } \\
\text { physical resources }(5=9.3 \%)\end{array}$ & $\begin{array}{l}\text { "Family is often not equipped (financially or } \\
\text { emotionally) to give or obtain effective care." } \\
\text { "... but they get tired and then they want to get } \\
\text { the person out of the house e.g. by placing him in } \\
\text { a centre". }\end{array}$ \\
\hline
\end{tabular}

The main sub-themes (Table 2) that emerged are discussed below.

\section{(a) Varying involvement of family members}

The first category identified by the majority of the participants $(27=50 \%)$ was that family members were uninvolved with the persons with disabilities. Narratives indicate that family members did not care much about these relatives and that they were not treating them well. 
The second category showed quite the opposite, because a significant number of participants $(18=40 \%)$ reported that families were in fact involved with the persons with disabilities and supported them. It is thus concluded that such involvement could be strong or weak, with slightly more participants noting that the bond between family members and the person with a disability was weak rather than strong.

\section{(b) The family is ignorant about the disability}

The only category identified in this sub-theme was that family members had insufficient information about the type of disability as well as the care required $(5=9.2 \%)$. This ignorance was also associated with a low level of education and poor socio-economic circumstances.

\section{(c) Insufficient resources in the family to support the person with a disability}

In this sub-theme the category identified by the fewest participants $(5=9.2 \%)$ was that the family had limited financial, emotional and physical resources, hampering effective caregiving. The family's resources were quickly exhausted, and they consequently preferred that the person be placed in a residential facility. Social workers also identified the family's lack of funds to make use of the existing community resources as an aspect that hampers preventative service delivery in child and family welfare organisations (Strydom, 2010).

\section{Problems which service providers observe when persons with disabilities are cared for in their families}

The participants were asked to describe the problems observed by service providers when persons with disabilities are cared for in their homes. The sub-themes, categories and the narratives of the participants are listed in Table 3.

TABLE 3

\section{THEME: PROBLEMS SERVICE PROVIDERS OBSERVE WHEN PERSONS WITH DISABILITIES ARE CARED FOR AT HOME}

\begin{tabular}{|c|c|c|}
\hline $\begin{array}{l}\text { SUB- } \\
\text { THEME }\end{array}$ & CATEGORIES & NARRATIVES \\
\hline \multirow[t]{2}{*}{$\begin{array}{l}\text { Lack of care } \\
\text { and } \\
\text { supervision } \\
(41=75.9)\end{array}$} & $\begin{array}{l}\text { 1. Poor physical } \\
\text { care }(21=38.9 \%)\end{array}$ & $\begin{array}{l}\text { "They are not provided with the right nutritious meals." } \\
\text { "Hygiene is severely neglected." } \\
\text { "Families struggle to wash/bath the disabled person." } \\
\text { "... medication is not given regularly or at the correct } \\
\text { times." } \\
\text { "Their care is neglected and their health deteriorates." }\end{array}$ \\
\hline & $\begin{array}{l}\text { 2. Ignorance } \\
\text { regarding care } \\
(16=29.6 \%)\end{array}$ & $\begin{array}{l}\text { "Families do not always have the necessary knowledge } \\
\text { about care-giving, especially when it concerns } \\
\text { bedsores." } \\
\text { "The care-giver does not have the training to care for the } \\
\text { person properly." } \\
\text { "Lack of insight into the risks of leaving somebody in the } \\
\text { middle-late phases of dementia without supervision." } \\
\text { "Is not well cared for because of ignorance and lack of } \\
\text { responsibility." }\end{array}$ \\
\hline
\end{tabular}




\begin{tabular}{|c|c|c|}
\hline $\begin{array}{l}\text { SUB- } \\
\text { THEME }\end{array}$ & CATEGORIES & NARRATIVES \\
\hline \multirow[t]{2}{*}{$\begin{array}{l}\text { Insufficient } \\
\text { financial } \\
\text { resources } \\
\text { for care in } \\
\text { the family } \\
(29=53.7 \%)\end{array}$} & $\begin{array}{l}\text { 1. Lack of } \\
\text { money and } \\
\text { resources to } \\
\text { provide effective } \\
\text { care }(15=27.8 \%)\end{array}$ & $\begin{array}{l}\text { "Most families cannot afford 'linen savers' and } \\
\text { diapers." } \\
\text { "Owing to financial restraints, most families cannot } \\
\text { afford home-carers." } \\
\text { "Resources, especially wheelchairs." }\end{array}$ \\
\hline & $\begin{array}{l}\text { 2. Houses are } \\
\text { not accessible } \\
(14=25.9 \%)\end{array}$ & $\begin{array}{l}\text { "Inaccessibility of homes/municipal flats - cannot move } \\
\text { around in wheelchair, access stairs." } \\
\text { "The difficulty of using the toilet because the space is too } \\
\text { small, also the bath space and (they) cannot move freely } \\
\text { with the chair." } \\
\text { "Houses have no bathrooms and water for washing and } \\
\text { cooking must be fetched." }\end{array}$ \\
\hline \multirow[t]{2}{*}{$\begin{array}{l}\text { Abuse of } \\
\text { persons with } \\
\text { disabilities } \\
(11=20.4 \%)\end{array}$} & $\begin{array}{l}\text { 1. Physical and } \\
\text { emotional abuse } \\
(7=13.0 \%)\end{array}$ & $\begin{array}{l}\text { "They are shouted at and slapped and they cannot help } \\
\text { being disabled." } \\
\text { "... they often sit at home without any company". } \\
\text { "... family's inability to handle changing/fluctuating } \\
\text { emotions (frustration, aggression, behavioural } \\
\text { problems/psychotic episodes)_of people with disabilities } \\
\text { positively". }\end{array}$ \\
\hline & $\begin{array}{l}\text { 2. Grants are } \\
\text { misspent } \\
(4=7.4 \%)\end{array}$ & $\begin{array}{l}\text { "...grant is misused/misspent." } \\
\text { "Misuse of grants." }\end{array}$ \\
\hline \multirow[t]{2}{*}{$\begin{array}{l}\text { Lack of } \\
\text { support } \\
\text { services in } \\
\text { the } \\
\text { community } \\
(7=13.0 \%)\end{array}$} & $\begin{array}{l}\text { 1. No support } \\
\text { for families } \\
\text { caring for } \\
\text { persons with } \\
\text { disabilities } \\
(5=9.3 \%)\end{array}$ & $\begin{array}{l}\text { "Too few home care-givers." } \\
\text { "Parents become tired and frustrated and cannot give } \\
\text { their best. A brother or sister must take over caring (of } \\
\text { the disabled person) if parents work." } \\
\text { "Lack of support from outside." }\end{array}$ \\
\hline & $\begin{array}{l}\text { 2. Lack of } \\
\text { stimulation } \\
(2=3.7 \%)\end{array}$ & $\begin{array}{l}\text { "There are few stimulating activities that the client can } \\
\text { do to keep busy." }\end{array}$ \\
\hline
\end{tabular}

Sub-themes (Table 3) that emerged as problems observed by service providers when persons with disabilities are cared for in their homes are discussed below.

\section{(a) Lack of care and supervision}

This sub-theme pertains to the lack of care and supervision for persons with disabilities mentioned by $41(76 \%)$ of the participants. A category identified was that the physical care of such persons was poor $(21=38.8 \%)$.

Another category points to the ignorance of family members regarding the care of persons with disabilities $(16=29.6 \%)$. This was also indicated in the previous section pertaining to the involvement of family members. 
A further category relates to the poor supervision of persons with disabilities ( $4=7.4 \%)$. The lack of care and supervision of the person when cared for by family members is a recurring theme in this study. Also, family members did not have sufficient knowledge about the disability itself.

\section{(b) Insufficient financial resources for care in the family}

Two categories are identified in this sub-theme, the first being that families lacked the money and resources to effectively care for persons with disabilities $(15=27.8 \%)$. Certain necessities such as diapers, and resources such as wheelchairs could not be afforded, and support services like home nursing were too expensive. The second category to emerge is that houses were not readily accessible $(14=25.8 \%)$, especially to wheelchair users, and that there was no running water in informal settlements to make bathing easier.

These findings, namely that the proper care of the person with a disability was severely affected by the scant financial means of the family, confirmed findings in other South African research which indicated, for example, that more than $80 \%$ of all disabled children in South Africa live in severe poverty, and in households with very low incomes and where the level of education is low (CASE, 1999; Gathiram, 2008; Graham et al., 2010). The lack of access to assistive aids (such as wheelchairs) is one of the biggest challenges (Visagie, Scheffler \& Schneider, 2013).

It was also found that the presence of a family member with a disability exacerbates the vulnerability of that family, especially where resources in the community are insufficient. The family member doing the caring will not be able to work (Graham et al., 2010). The fact that families who are responsible for the care of such a family member experience financial stress is also confirmed by research in other countries. It was found in Australia, for example, that these families experience more problems to pay for electricity, gas and telephone services than do the rest of the population. Many carers also had to relinquish jobs to care for the disabled person, which adversely affected their financial situation (Edwards, Higgins, Gray, Zmijewski \& Kingston, 2008).

\section{(c) Abuse of persons with disabilities}

The category that emerged in this sub-theme is that persons with disabilities in the family were ill-treated physically and emotionally $(7=13 \%)$. In the United Kingdom it was found that persons with disabilities were at a higher risk of victimisation than persons with no disabilities. Physical incidents, such as assault, were the most common types of violence and hostility, occurring often in the home and residential institutions (Sin, Hedges, Cook, Mguni \& Comber, 2009). In Brown, Cohen, Johnson and Salzinger's (1998) research it was also found that disabled children run a higher risk for child abuse and neglect.

Another category relates to the disability grants being misspent $(4=7.4 \%)$. This misapplication of grants could probably be associated with the facts mentioned in the previous section, namely that the family did not have the financial resources to care for the person with a disability, who was therefore in a more vulnerable situation. Graham et 
al. (2010) found that money from the grant is often used to cover basic needs, such as food, and is not utilised toward providing care or the aids required for the person in need. This finding also corresponds with research in Australia, where it was found that families caring for a disabled family member had problems settling household accounts (Edwards et al., 2008).

\section{(d) Lack of support services in community}

A minority $(7=13 \%)$ of the participants subscribed to this sub-theme. The category was associated with a lack of support for the family caring for a person with a disability $(5=9.3 \%)$ and a lack of sufficient home-care services.

This finding corresponds with the findings of Edwards et al. (2008). Care-givers in this Australian study revealed significantly poorer spiritual health as well as a higher incidence of depression than the rest of the population. Associated with the poorer spiritual and physical health of the care-givers were, for example, the demands made by a person who needs specialised care. One out of every five care-givers did not have access to a care network.

The lack of community services providing stimulation to the person with a disability $(2=3.7 \%)$ was identified by a small number of the participants as a problem encountered by service providers. A lack of community resources places more stress on the family to meet the needs of the person with a disability. This lack also affects family preservation services as identified in other South African research (Strydom, 2010).

\section{CARE OF PERSONS WITH DISABILITIES IN RESIDENTIAL FACILITIES}

The views of service providers were sought on the care of persons with disabilities in residential facilities. This was important because the primary focus of family preservation is on keeping the child within the family, although in certain situations it could be in the best interests of the child to be placed in alternative care. Similarly it could sometimes be in the best interest of the person with a disability to be cared for in a residential facility.

\section{Views on why persons with disabilities should be cared for in residential facilities rather than at home}

The participants were asked to supply reasons why persons with disabilities should be cared for in residential facilities rather than at home. The sub-themes, categories and narratives of the participants are presented in Table 4. 


\section{TABLE 4}

\section{THEME: WHY PERSONS WITH DISABILITIES SHOULD BE CARED FOR IN RESIDENTIAL FACILITIES}

\begin{tabular}{|c|c|c|}
\hline SUB-THEME & CATEGORIES & NARRATIVES \\
\hline \multirow[t]{3}{*}{$\begin{array}{l}\text { Higher quality of } \\
\text { care }(39=72.2 \%)\end{array}$} & $\begin{array}{l}\text { 1. Better physical } \\
\text { care }(19=35.1 \%)\end{array}$ & $\begin{array}{l}\text { "The necessary physical needs will be taken } \\
\text { care of every day." } \\
\text { "People get their food timeously as well as } \\
\text { their medication." }\end{array}$ \\
\hline & $\begin{array}{l}\text { 2. Trained care- } \\
\text { givers }(13=24.0 \%)\end{array}$ & $\begin{array}{l}\text { "Trained staff are better able to care for the } \\
\text { emotional and physical needs of disabled } \\
\text { people." } \\
\text { "The parents/family do not always have the } \\
\text { necessary knowledge and experience to handle } \\
\text { the person." }\end{array}$ \\
\hline & $\begin{array}{l}\text { 3. Facilities are } \\
\text { better equipped } \\
(7=13.0 \%)\end{array}$ & $\begin{array}{l}\text { "Facilities are better equipped e.g. to } \\
\text { accommodate wheelchairs." } \\
\text { "Homes are usually small and not equipped for } \\
\text { disabled persons." }\end{array}$ \\
\hline \multirow{3}{*}{$\begin{array}{l}\text { Overall } \\
\text { development of } \\
\text { person with a } \\
\text { disability is } \\
\text { improved } \\
(13=24.0 \%)\end{array}$} & $\begin{array}{l}\text { 1. The person with a } \\
\text { disability is } \\
\text { stimulated }(5=9.2 \%)\end{array}$ & $\begin{array}{l}\text { "Daily exercise is needed." } \\
\text { "Regular stimulation" }\end{array}$ \\
\hline & $\begin{array}{l}\text { 2. "Independence is } \\
\text { promoted" }(4=7.4 \%)\end{array}$ & $\begin{array}{l}\text { "... to promote the disabled person's } \\
\text { independence. } " \\
\text { "Independence is enhanced." }\end{array}$ \\
\hline & $\begin{array}{l}\text { 3. Social interaction } \\
\text { is promoted } \\
(4=7.4 \%)\end{array}$ & $\begin{array}{l}\text { "Social interaction with peers takes place." } \\
\text { "Social contact with other people with the } \\
\text { same problem." }\end{array}$ \\
\hline \multirow[t]{3}{*}{$\begin{array}{l}\text { Family not able to } \\
\text { care for person } \\
\text { with a disability } \\
(11=20.4 \%)\end{array}$} & $\begin{array}{l}\text { 1. Substance abuse } \\
\text { takes place } \\
(3=5.5 \%)\end{array}$ & $\begin{array}{l}\text { "Parents abuse alcohol and this leads to } \\
\text { neglect." } \\
\text { "Alcohol abuse and everything associated with } \\
\text { this." }\end{array}$ \\
\hline & $\begin{array}{l}\text { 2. Abuse and neglect } \\
\text { of person with a } \\
\text { disability }(6=11.1 \%)\end{array}$ & $\begin{array}{l}\text { "Prevention of violence." } \\
\text { "Neglect, abuse, and inability to protect the } \\
\text { person with disability." }\end{array}$ \\
\hline & $\begin{array}{l}\text { 3. Misapplication of } \\
\text { grant }(2=3.7 \%\end{array}$ & $\begin{array}{l}\text { "Family misuses grant meant for the disabled } \\
\text { person." } \\
\text { "Their grants are not used for them and they } \\
\text { are neglected." }\end{array}$ \\
\hline
\end{tabular}

The sub-themes (Table 4) derived from the data are discussed below. 


\section{(a) Higher quality of care}

It is clear from Table 4 that the majority of the narratives $(39=72.2 \%)$ in this sub-theme dealt with the overall care of the person with a disability. In the first category it is noted that persons with disabilities could be better cared for in a residential facility $(19=35.1 \%)$. In the second category the view is that care-takers in a residential facility were specifically trained $(13=24.0 \%)$ to care for persons with disabilities, which naturally improves the quality of care. In the last category in this theme it is noted that the residential facility is better equipped to accommodate persons with disabilities $(7=13.0 \%)$ in that, for example, it is wheelchair friendly.

\section{(b) Overall development of persons with disabilities}

The second sub-theme concerns the overall development of the person with a disability $(13=24 \%)$. Three sub-themes in this category were highlighted, namely that people receive more stimulation in a residential facility $(5=9.2 \%)$, and that their independence $(4=7.4 \%)$ and their social interaction $(4=7.4 \%)$ are enhanced.

\section{(c) The family is unable to care for the person with a disability}

The last sub-theme is that the family is not capable of caring for the person with a disability $(11=20.4 \%)$. The categories identified are that the family of the person with a disability abuse and neglect him/her $(6=11.1 \%)$, that substance abuse takes place $(3=5.5 \%)$ and that the disability grant is misused $(2=3.7 \%)$.

It is concluded that the reasons given by the participants for the admission of persons with disabilities to residential facilities correspond to a large extent with the problems experienced by service providers when persons with disabilities are being cared for at home. The first two categories could be addressed by good community-based support programmes for the families concerned. The last sub-theme, where the person is abused and neglected, should be an important reason for considering residential care.

\section{FOCUS OF FAMILY PRESERVATION SERVICES FOR PERSONS WITH DISABILITIES}

The participants were requested to indicate what the focus of family preservation services for persons with disabilities should be. The data obtained are presented in Table 5. 


\section{TABLE 5}

VIEWS OF SERVICE PROVIDERS ON ASPECTS THAT SHOULD BE FOCUSED ON IN FAMILY PRESERVATION SERVICES FOR PERSONS WITH DISABILITIES

\begin{tabular}{|c|c|c|}
\hline $\begin{array}{l}\text { SUB- } \\
\text { THEMES }\end{array}$ & CATEGORIES & NARRATIVES \\
\hline \multirow[t]{2}{*}{$\begin{array}{l}\text { Care of person } \\
\text { with a } \\
\text { disability }\end{array}$} & $\begin{array}{l}\text { 1. Empower family } \\
\text { through training to } \\
\text { manage care of } \\
\text { person with a } \\
\text { disability } \\
(13=24.0 \%)\end{array}$ & $\begin{array}{l}\text { "Full spectrum of training with regard to the needs } \\
\text { of the disabled person, development milestones, } \\
\text { social needs and integration." } \\
\text { "The family members responsible for the disabled } \\
\text { person should be trained in all aspects of care." }\end{array}$ \\
\hline & $\begin{array}{l}\text { 2. Knowledge of the } \\
\text { type of disability } \\
\text { must be addressed in } \\
\text { order to develop } \\
\text { management skills } \\
(10=18.5 \%)\end{array}$ & $\begin{array}{l}\text { "Training sessions with the family regarding the } \\
\text { disabled person's condition." } \\
\text { "Training with regard to disability and the } \\
\text { challenges associated with the specific disability." }\end{array}$ \\
\hline $\begin{array}{l}\text { Support of the } \\
\text { family }\end{array}$ & $\begin{array}{l}\text { 1. Support through } \\
\text { counselling in order } \\
\text { to strengthen family } \\
\text { bonds }(7=13.0 \%)\end{array}$ & $\begin{array}{l}\text { "Families must receive counselling - families do } \\
\text { not plan for a disabled child." } \\
\text { "Include the family in sessions with the disabled } \\
\text { person." } \\
\text { "New roles in cases where the person has recently } \\
\text { become disabled. Better relationships between } \\
\text { people." }\end{array}$ \\
\hline \multirow[t]{2}{*}{$\begin{array}{l}\text { Development } \\
\text { of resources in } \\
\text { the community }\end{array}$} & $\begin{array}{l}\text { 1. Development of } \\
\text { alternative care } \\
\text { possibilities } \\
(4=7.4 \%)\end{array}$ & $\begin{array}{l}\text { "Employment of more home-care workers in } \\
\text { different communities." } \\
\text { "Additional help e.g. HRCs who could help with } \\
\text { basic care." } \\
\text { "Help from volunteers." }\end{array}$ \\
\hline & $\begin{array}{l}\text { Day-care facilities } \\
(2=3.7 \%)\end{array}$ & $\begin{array}{l}\text { "Engagement of disabled person in day-care } \\
\text { programmes so that care-givers can rest." } \\
\text { "Day-care centre for frail PWD under the age of } 60 \\
\text { years." }\end{array}$ \\
\hline
\end{tabular}

The main sub-themes that emerged as indicated in Table 5 are discussed below.

\section{(a) Care of person with a disability}

The first sub-theme identified by most participants $(23=42.6 \%)$ is that the focus of family preservation should be on the care of the person with a disability. Two categories were identified, namely that the family should be empowered through training programmes $(13=24.0 \%)$ to better manage the care required, and knowledge of disabilities as well as of types of disabilities should be expanded so that the families' handling skills could be improved $(10=18.5 \%)$. Both categories correspond with the aims of family preservation (Tracy, 1995:974), namely the strengthening of families' 
coping skills so that children, or persons with disabilities for the purpose of this study, can be cared for effectively. This type of intervention often focuses on educational services, strengthening the skills of the family (Martens, 2009; Mullins et al., 2011).

\section{(b) Support of the family}

In this sub-theme the only category and the narratives relate to the fact that families caring for persons with disabilities should be supported through counselling $(7=13.0 \%)$, which accords with the extension of the family's skills with regard to managing the person, as well as strengthening the family bonds, which is an important component of family preservation (Tracy, 1995). These services are usually therapeutic in nature and should be rendered, for example, during family counselling sessions (Cash \& Berry, 2003; Juby \& Rycraft, 2004; Mullins et al., 2011).

\section{(c) Development of resources in the community}

In this sub-theme two categories were identified, namely the development of possible alternative ways for the family to care for the disabled (4=7.4\%) and the development or availability of day-care facilities $(2=3.7 \%)$. These categories are associated with the fact that families must be empowered during effective family preservation programmes to make use of formal and informal resources in the community (Tracy, 1995:974). Possible alternative ways of caring mentioned by participants in their narratives focused especially on the delivery of home-visiting services or home-care services by home-care workers trying to support the family. Home-based care is also emphasised in South African policy documents (Republic of South Africa, 1997; Republic of South Africa, Western Cape Department of Social Development, n.d.).

Home-visiting programmes are considered in America (Olds, 2003) and the United Kingdom (Gibbons \& Thorpe, 1989) as an important support service rendered to families involved in family preservation programmes. Although a minority of the participants focused on the resources that should exist in the community or which should be developed, these support services form an important part of effective family preservation services. It is clear that the aspects to be addressed in the rendering of family preservation services for people with disabilities, according to the participants, correspond with the aims of family preservation as indicated by Tracy (1995:974).

\section{CONCLUSIONS}

Most of the service providers identified insufficient funds to render effective services as the greatest obstacle. This lack of funds causes a shortage of professional and paraprofessional staff to render comprehensive services. Another obstacle is that communities lack sufficient resources, for example, suitable public transport for persons with disabilities. Inadequate transport means that programmes and other services provided by service providers are not accessible. Service providers in turn often do not have enough vehicles for home visits, which means that both parties experience obstacles when trying to reach each other. These obstacles are also experienced in the child and family welfare field in South Africa. Such structural problems in organisations and communities are not within the power of service providers to address. Rendering effective social work services in poverty-stricken communities where there is a lack of 
resources in the community as well as the NGOs is therefore very challenging and almost impossible.

Service providers' experience of the involvement of family members in the care of relatives with a disability seems to differ as slightly more participants noted that the bond between family members and the relative needing care was weak rather than strong. Families furthermore did not have sufficient financial, emotional and physical resources to provide effective care.

More than $75 \%$ of the service providers reported a lack of care and supervision when home care was attempted. Especially the physical care was poor, probably caused by the ignorance of family members regarding the care of persons with disabilities, as well as of care suited to a specific form of disability.

More than half of the participants indicated that a lack of financial means was a problem, as it directly affects the care and quality of life of the person in care. Houses can, for example, not be adapted to accommodate wheelchair users and in informal settlements there are often no baths or even running water to allow for proper care. The lack of funds also means that families cannot acquire the necessary equipment and resources such as wheelchairs, and that home care with its financial implications is out of reach. Physical and emotional abuse of persons with disabilities was identified as another problem. An associated aspect is that the disability grant is often misspent. It is clear that poverty severely affects the care of a person living with a disability.

Although in South Africa people with disabilities often live within the family, there seems to be a shortage of support programmes for such families in existing services. This finding corresponds with the fact that only a minority of the participants identified the lack of support services in communities like home-visiting/care services for families, as well as the lack of services that can stimulate the person with a disability, as a problem. There thus seems to be a lack of awareness about the importance of support services for families who are caring for a relative, which could lead to burnout in carers and poor care and abuse of the person with a disability, as it is expected of carers to do the caring without sufficient training or support.

The opinions of participants on why persons with disabilities should be cared for in residential facilities rather than at home corresponded to a large extent with the problems experienced with care in the home. In residential facilities better physical care is available, mainly because there are trained care-givers. Residential facilities are also designed specifically with an eye to a more accessible environment. The development of residents is enhanced, as they are stimulated while their independence and social interaction are also promoted through contact with peers.

As to what the focus should be in the delivery of family preservation services, most of the participants were of the opinion that the care of relatives by the family should be emphasised and that the family should be empowered through training programmes to obtain knowledge of the specific disability. The family should also be supported by counselling to enhance and strengthen family bonds. The development of community resources geared towards people with disabilities is another aspect which should receive 
attention in a family preservation programme - for example, the utilisation of more home-care workers (home visitors) as well as the establishment of day-care facilities where persons with disabilities could be engaged could support family members in their roles as care-givers. These aspects accord with the aims of family preservation and should thus be taken into consideration by NGOs rendering social work services to persons with disabilities. People needing care should, however, rather be admitted to a residential facility in the event of substance abuse, physical abuse or neglect.

\section{RECOMMENDATIONS}

The care of persons with disabilities in their homes is adversely affected by insufficient funds in organisations, insufficient finances in families and insufficient resources in communities. There seems, however, to be a clear link between the aims of family preservation services and the needs of families caring for a relative with a disability. Should family preservation services for people with disabilities be developed, it is recommended that the following aspects be considered:

- The empowering of families through training programmes to develop skills and to enable family members to care for disabled family members at home;

- Support for the family through counselling to promote good relationships and a mutual understanding between the family and the person needing care. This in turn would improve the family's management skills of the specific disability and strengthen the family bonds;

- Developing community resources such as home-based care to support the family and the person with a disability, with an eye to effective integration into the community.

NGOs delivering social work services to people with disabilities could, however, not develop and implement appropriate family preservation services as it has already been established that they do not have the financial means to sustain even existing programmes effectively. Furthermore, family preservation services will only be effective if services are developed that could support families on an individual level, as well as on the community level, and where services include intensive family preservation services, family-centred services and community-based support services. Organisations delivering services to people with disabilities, however, could enhance service rendering by including family preservation principles in their current in-service training of social workers, as well as their existing programmes, as a clear link between the aim of family preservation services and the needs of families caring for a relative with a disability has been established.

\section{REFERENCES}

AL, C.M.W., STAMS, G.J.J.M., BEK, M.S., DAMEN, E.M., ASSCHER, J.J. \& VAN DER LAAN, P.H. 2012. A meta-analysis of intensive family preservation programs: placement prevention and improvement of family functioning. Children and Youth Services Review, (2012). doi. 10.1016/childyouth.2012.04.002. 
ARMSTRONG, C. \& HILL, M. 2001. Support services for vulnerable families with young children. Child and Family Social Work, 6(4):351-358.

BROWN, J., COHEN, P., JOHNSON, J. \& SALZINGER, S. 1998. A longitudinal analyses of risk factors for child maltreatment: findings of a 17 year prospective study of officially recorded and self-reported child abuse and neglect. Child Abuse and Neglect, 22(11):1065-1078.

BROWN, M. \& NEKU, R.J. 2005. A historical review of the South African social welfare system and social work practitioners' views on its current status. International Social Work, 48(3):301-312.

CASH, S.J. \& BERRY, M. 2003. The impact of family preservation services on child and family well-being. Journal of Social Service Research, 29(3):1-26.

CHAFFIN, M., BONNER, B.L. \& HILL, R.F. 2001. Family preservation and family support programs: Child maltreatment outcomes across client risk levels and program types. Child Abuse and Neglect, 25(10):1269-1289.

CHITEREKA, C. 2014. People with disabilities and the role of social workers in Lesotho. Social Work and Society, 12(1). [Online] Available: http://www.socwork. net/sws/article/view/25/89.

COMMUNITY AGENCY FOR SOCIAL ENQUIRY (CASE). 1999. "We also count!" The extent of moderate and severe reported disability and the nature of the disability experience in South Africa. Report for South African Department of Health.

DE VOS, A.S., STRYDOM, H., FOUCHÉ, C.B. \& DELPORT, C.S.L. 2011. Research at grass roots: for the social sciences and human service professions $\left(4^{\text {th }} \mathrm{ed}\right)$. Pretoria: Van Schaik Publishers.

DEPARTMENT OF SOCIAL DEVELOPMENT, DEPARTMENT OF WOMEN, CHILDREN, AND PEOPLE WITH DISABILITIES \& UNICEF. 2012. Children with Disabilities in South Africa: A Situation Analysis: 2001-2011. Pretoria.

EDWARDS, B., HIGGINS, V.M., GRAY, M., ZMIJEWSKI, N. \& KINGSTON, M. 2008. The nature and impact of caring for family members with a disability in Australia. Australian Institute of Family Studies.

FOUCHÉ, C.B. \& DE VOS, A.S. 2005. Quantitative research designs. In: DE VOS, A.S., STRYDOM, H., FOUCHÉ, C.B. \& DELPORT, C.S.L. Research at grass roots: for the social sciences and human service professions $\left(3^{\text {rd }}\right.$ ed). Pretoria: Van Schaik Publishers, 132-143.

GATHIRAM, N. 2008: A critical review of the developmental approach to disability in South Africa. International Journal of Social Welfare, 17(2):146-155.

GIBBONS, J. \& THORPE, S. 1989. Can voluntary support projects help vulnerable families? The work of Home-Start. British Journal of Social Work, 19:189-202. 
GRAHAM, L., SELIPSKY, L., MOODLEY, J., MAINA, J. \& ROWLAND, W. 2010. Understanding poverty and disability in Johannesburg. Centre for Social Development in Africa (CSDA) and Department for International Development United Kingdom (DFID).

JUBY, C. \& RYCRAFT, J.R. 2004. Family preservation strategies for families in poverty. Families in Society: The Journal of Contemporary Human Services, 85(4):581-590.

LORENZO, T. \& CRAMM, J.M. 2012. Access to livelihood assets among youth with and without disabilities in South Africa: Implications for health professional education. SAMJ, 102(6):568-881.

MAJA, P.A., MANN, W.M., SING, D., STEYN, A.J. \& NAIDOO, P. 2011. Employing people with disabilities in South Africa. South African Journal of Occupational Therapy, 41(1):24-33.

MALUCCIO, A.N., PINE, B.A. \& TRACY, E.M. 2002. Social work practice with families and children. New York: Columbia University Press.

MARTENS, P. 2009. IFPS toolkit. National Family Preservation Network.

MULLINS, J.L., CHUENG, J.R. \& LIETZ, C.A. 2011. Family preservation services: incorporating the voice of families into service implementation, Child and Family Social Work. doi. 10.111/j. 1365-2206.2011.00777.

OLDS, D. 2003. Reducing program attrition in home visiting: what do we need to know? Child Abuse and Neglect, 27(4):359-361.

PECORA, J., FRASER, M.W., NELSON, K.E., McCROSKEY, J. \& MEEZAN, W. 1995. Evaluating family based services. New York: Hawthorne.

PHILLPOTT, S. \& McLAREN, P. 2011. Hearing the voices of children and caregivers: situation analysis of children with disabilities in South Africa. Pretoria: Department of Social Development/ UNICEF.

PIERSON, J. 2002. Tackling social exclusion. London: Routledge.

PITHOUSE, A. \& TASIRAN, A. 2000. Local authority family centre intervention: a statistical exploration of services as family support or family control. Child and Family Social Work, 5(4):129-141.

REPUBLIC OF SOUTH AFRICA. 1997. South Africa: Integrated National Disability Strategy: White Paper.

REPUBLIC OF SOUTH AFRICA. n.d. Western Cape Department of Social Development: Policy on Disability. [Online] Available: https://www.westerncape. gov.za/social.

RYAN, J.P. \& SCHUERMAN, J.R. 2004. Matching families with specific family preservation services: a study of service effectiveness. Children and Youth Services Review, 26(4):347-472. 
SIN, C.H., HEDGES, A., COOK, C., MGUNI, N. \& COMBER, N. 2009. Disabled people's experiences of targeted violence and hostility. Research Report 21. Manchester, England.

SOUTH AFRICAN HUMAN RIGHTS COMMISSION. 2006. The intersection of equality and disability in the work of the South African Human Rights Commission. Submission to Constitutional Review Committee.

STATISTICS SOUTH AFRICA. 2014. Census 2011. Profile of persons with disabilities in South Africa. Pretoria.

STREAK, J. \& POGGENPOEL, S. 2005. Towards social welfare services for all vulnerable children in South Africa: a review of policy development, budgeting and service delivery. Children's Budget Unit, Budget information Service, Idasa. 31 March 2005 .

STRYDOM, H. 2005. Sampling and sampling methods. In: DE VOS, A.S., STRYDOM, H., FOUCHÉ, C.B. \& DELPORT, C.S.L. Research at grass roots: for the social sciences and human service professions $\left(3^{\text {rd }}\right.$ ed). Pretoria: Van Schaik Publishers, 192-204.

STRYDOM, M. 2008. Maatskaplike werkers by gesinsorgorganisasies se perspektief op gesinsinstandhoudingsdienste aan hoërisiko-gesinne. Stellenbosch: Universiteit van Stellenbosch. (DPhil proefskrif)

STRYDOM, M. 2010. The implementation of family preservation services: perspectives of social workers at NGOs. Maatskaplike Werk/Social Work, 46(2):192-208.

TRACY, E.M. 1995. Family preservation and home-based services. Encyclopedia of Social Work $\left(19^{\text {th }}\right.$ ed). Washington: NASW Press, 973-981.

VISAGIE, S., SCHEFFLER, E. \& SCHNEIDER, M. 2013. Policy implementation in wheelchair service delivery in a rural South African setting. African Journal of Disability, 2(1). [Online] Available: http://www.ajod.org/index.php/ajod/article/ view/63/105.

WARREN-ADAMSON, C. 2006. Research review. Family centres: a review of the literature. Child and Family Social Work, 11(2):171-182.

WEYERS, M.L. \& VAN DEN BERG, A.M. 2006. The success factors in community work services: a critical incident study. International Social Work, 49(2):177-187.

Dr Marianne Strydom, Department of Social Work, Stellenbosch University, Stellenbosch, South Africa. 